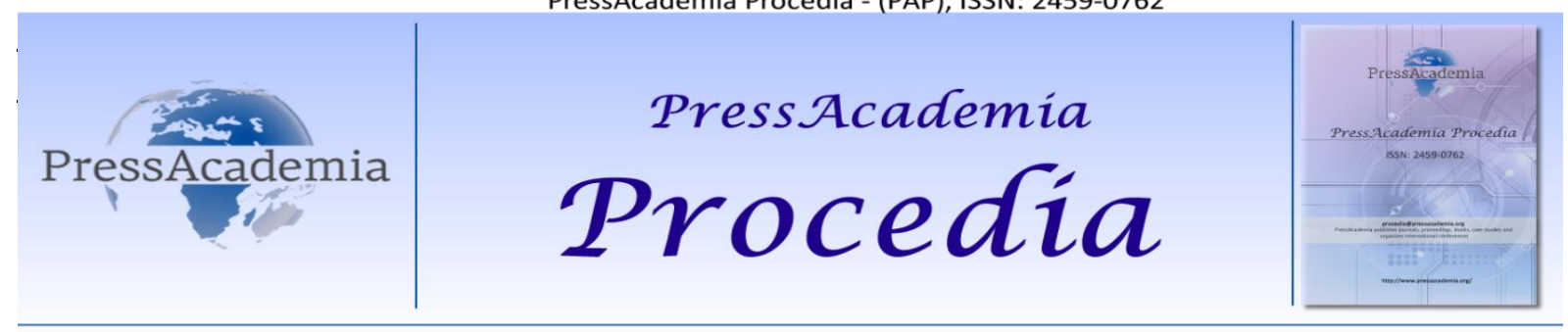

Global Business Research Congress (GBRC), May 24-25, 2017, Istanbul, Turkey

\title{
DETERMINATION OF SMARTPHONE BRAND PEREFERENCES VIA MARKOV CHAIN ANALYSIS: A CASE STUDY ON UNIVERSITY 1ST GRADERS
}

\section{DOI: 10.17261/Pressacademia.2017.643 \\ PAP- GBRC-V.3-2017(69)-p.674-684}

\author{
Hatice Handan Oztemiz ${ }^{1}$, Handan Guler Iplikci ${ }^{2}$ \\ ${ }^{1}$ Alanya Alaaddin Keykubat University, Faculty of Business, Antalya. handanoztemiz@gmail.com \\ ${ }^{2}$ Manisa Celal Bayar University, School of Application Sciences, Manisa. handan_pr@hotmail.com
}

\section{To cite this document}

Oztemiz, H. H. and H. G. Iplikci (2017). Determination of smartphone brand pereferences via markov chain analysis: a case study on university 1st graders. PressAcademia Procedia (PAP), V.3, p.674-.684.

Permemant link to this document: $\underline{\text { http://doi.org/10.17261/Pressacademia.2017.643 }}$

Copyright: Published by PressAcademia and limited licenced re-use rights only.

\begin{abstract}
Smart phones that are getting functional as much as computers coupled with the development in technology are the most frequently used communication instruments in our lives. This widespread use of smartphones has enabled them to focus on consumer work by influencing the efforts of manufacturers to prioritize brands. The purpose of this study is to determine smartphone preferences and to estimate the market share of mobile phone manufacturers in the long term by determining the transitions between the intended brands. The extensive usage of smart phones, ensure the producing companies efforts affectionally to focus towards consumers to bring their brands into the forefront. To determine the smart phone brand preference a questionnaire is conducted on 200 first grade students in the university departments Applied Sciences International Trade and Banking and Finance department in Celal Bayar University. From all this questionnaires, it is seen that 153 questionnaires could be used because of missing data. Participants of the questionnaires are asked about their currently used smart phone brands and the previously used smart phone brands. The Markov Chains are used in the analyze of the smart phone brand preferences. The Markov transition probability matrixes are constituted considering the numbers between the transitions from a smart phone to another smart phone brand. Among the phone brands that students have used before, Samsung maintains leadership with $47 \%$, followed by Nokia with $18 \%$, iPhone with $15.6 \%$ and Sony with $6,5 \%$. Among the phone brands used by students at the moment, Samsung has reached 32\% with the iPhone, 27\% with the iPhone, $12.4 \%$ with LG and $8.4 \%$ with GM. After the analyses it is concluded that the most preferred brands would be $45 \%$ for Iphone, $24 \%$ for Samsung, $10 \%$ for LG, $6 \%$ for General Motors and $5 \%$ for Sony in long term.
\end{abstract}

Keywords: Smart Phone, Brand Preference, Markov Chain Analysis, Steady-State Vector, Stochastic Processes. JEL Codes: M30, M31, M39.

\section{MARKOV ZINCIRLERI iLE AKILLI TELEFON MARKA TERCIHININ BELIRLENMESI: ÜNIVERSITE 1. SINIF ÖĞRENCILERI ÜZERINDE ÖRNEK UYGULAMA}

\section{ÖZET}

Teknolojinin gelişmesiyle birlikte bilgisayarlar kadar işlevsel hale gelen akıllı telefonlar gün içerisinde en sık kullanılan iletişim araçları olarak hayatımızda yer almaktadır. Akılı telefonların bu denli yaygın kullanımı üretici firmaların markalarını ön plana çıkarma çabalarını etkileyerek tüketicilere yönelik çalışmalara odaklanmalarını sağlamıştır. Bu çalışmanın amacı akıllı telefon marka tercihlerini belirlemek ve markalar arası geçişleri belirleyerek uzun dönemde cep telefonu üreticilerinin pazar payını tahmin etmektir. Bu çalışmada akıllı telefon marka tercihlerinin belirlenmesi için Celal Bayar Üniversitesi Uygulamalı Bilimler Yüksekokulu Uluslararası Ticaret bölümü ve Bankacılık ve Finans bölümleri birinci sınıf 200 öğrenciye anket uygulanmıştır. Bu anketlerden 153 âdetinin kullanılabilir olduğu, kalanının ise eksik veri sebebiyle uygulama dışı olduğu görülmüştür. Ankete katılan kişilere şu anda kullanmakta oldukları ve bir önceki dönemde kullanmış oldukları akıllı telefon markaları sorulmuştur. Akıllı telefon marka tercihlerinin analizinde Markov zincirlerinden yararlanılmıştır. Markov geçiş olasılıkları matrisi herhangi bir akıllı telefon markasından diğer akıllı telefon markasına geçiş sayıları dikkate alınarak oluşturulmuştur. Öğrencilerin önceki kullandıkları telefon markaları arasında \%47 ile Samsung liderliğini korurken, bunu \% 18 ile Nokia, \% 15,6 ile İphone ve \% 6, 5 ile Sony takip etmekte olduğu bulunmuştur. Şuanda kullanmakta oldukları telefon markalarının \%32 ile Samsung, \%27 ile İphone, \%12,4 ile LG ve $\% 8,4$ ile GM olduğu tespit edilmiştir. Analizde uzun dönemde \% 45 oran ile Iphone, \%24 ile Samsung, \%10 ile LG, \% 6 ile General Motors ve \% 5 ile Sony marka akıllı telefonların en çok tercih edilen markalar olacağı sonucuna varılmıştır.

Anahtar Kelimeler: Cep Telefonu, Marka Tercihleri, Markov Zincirleri Analizi, Denge durum vektörü, Stokastik Süreçler JEL Kodları: M30, M31, M39. 


\section{GíRiş}

Teknolojinin gelişmesiyle birlikte bilgisayarlar kadar işlevsel hale gelen, hatta bilgisayarlardan pek farkı kalmayan akıllı telefonlar günlük hayatımızda en sık kullanılan iletişim araçları olarak varlıklarını sürdürmektedir. Teknolojik donanımı sürekli geliştirilen ve buna paralel olarak kullanım oranı sürekli artmakta olan akıllı telefonlar, telefon işlevinin yanı sıra barındırdığı birçok özellikle tüketicilerin hayatını kolaylaştırmaktadır. Akılı telefonların bu denli yaygın kullanımı üretici firmaların markalarını ön plana çıkarma çabalarını etkileyerek tüketicilere yönelik çalışmalara odaklanmalarını sağlamıştır. Dünya genelinde daha çok genç tüketicilerde cep telefonu kullanımı artışı göze çarpmakta, gençlerin teknolojiyi ve yenilikleri hızlı benimsemesi üretici firmaların pazarlama odağında bu grubun yer alması söz konusudur (Khan ve Rohi,2013: 369) . Yani akıllı telefon üreticilerinin hedef kitlesi daha çok gençlerden oluşmakta, özellikle de teknolojik gelişmeleri daha yakından ve ilgiliyle takip eden üniversite öğrencileri bu pazar için önemlilik arz etmektedir (Gülmez, 2005: 37).

Yeni nesil cep telefonları, konuşmanın ve kısa mesaj servisinin yanı sıra bilgisayar özelliği, mp3 müzik dinleme, video izleme ve yayınlama, fotoğraf çekme özelliği, ajanda, kilo kaydı, yürüme mesafesi hesaplama, hesap makinesi, internet bağlantısı internet bankacılığı, sosyal medyaya ulaşım gibi daha pek çok özelliği ile insanların vazgeçilmezi olmuştur. Akıllı telefon piyasasında aynı markaya ait yeni ürünün piyasaya girmesi, bir önceki ürünü takiben aşağı yukarı en fazla 6 ay sürmektedir. Piyasada birden çok marka telefonu üstelik aynı markaya ait envai çeşit ürünü aynı anda bulan tüketicinin sahip olma duygusu tetiklenmektedir. Diğer yandan günümüzde insan, kullanmayı tercih ettiği markalar ile kimliklerini simgelemektedir. Bu durumun en iyi örneklerinden biri ise yine cep telefonları markalarında görülmektedir. Örneğin klavyesinin özelikleri sebebiyle Blackberry marka cep telefonları, genel olarak iş adamlarının kullandığı telefonlar olarak nitelendirilebilmektedir. Diğer yandan Iphone ve Samsung marka telefonlar ise günümüzde sık model değiştiren ve özellikle birbirleriyle sıkı bir rekabette olan piyasanın önemli aktörlerindendir. Fiyat olarak farklılaşan bu markalar, uygulama olarak birbirine benzeyen programlarla ürünlerini genişletmektedir. Ömürbek ve Şimşek (2012), İphone marka cep telefonlarının yüksek gelir grubuna hitap ettiğini, daha fonksiyonel olmasının yanı sıra, fiyatlamasının yüksek olması sebebiyle daha dar bir alana sahip olmasının avantajını yaşadığını belirtmiştir. 2012 yılından günümüze cep telefonu alışverişinde kredi kartı taksitlendirme olanaklarının düşürülmesi aslında bu durumun tersini ifade etmektedir, taksitli alış veriş ile pek çok insan pahalı ürünlere ulaşabilmektedir. Yani günümüzde İphone yüksek gelir grubuna hitap eden bir telefonda olsa, artık hemen hemen herkesin elinde olan yaygın ürünlerden biridir. Türkiye'de 2000-2015 dönem arasında cep telefonu aboneliğini Çizelge $1^{\prime}$ de gösterilmektedir. Çizelge 1'de de görüldüğü üzere 2000 yılında Türkiye'de 1.613 milyon kişi cep telefonu abonesiyken, bu rakam her yıl katlanarak artmış 2015 yılında 73.639 milyon kişiye ulaşmıştır. Bu rakamlar cep telefonu abone sayısını göstermektedir. Yani Türkiye'deki kişi sayısından ziyade abonelik sayısıdır. Daha açık bir ifade ile bir kişinin birden çok aboneliğinin olabileceğini belirtmektedir.

Grafik 1: Türkiye ‘de Cep Telefonu Abone Sayısının Değişimi

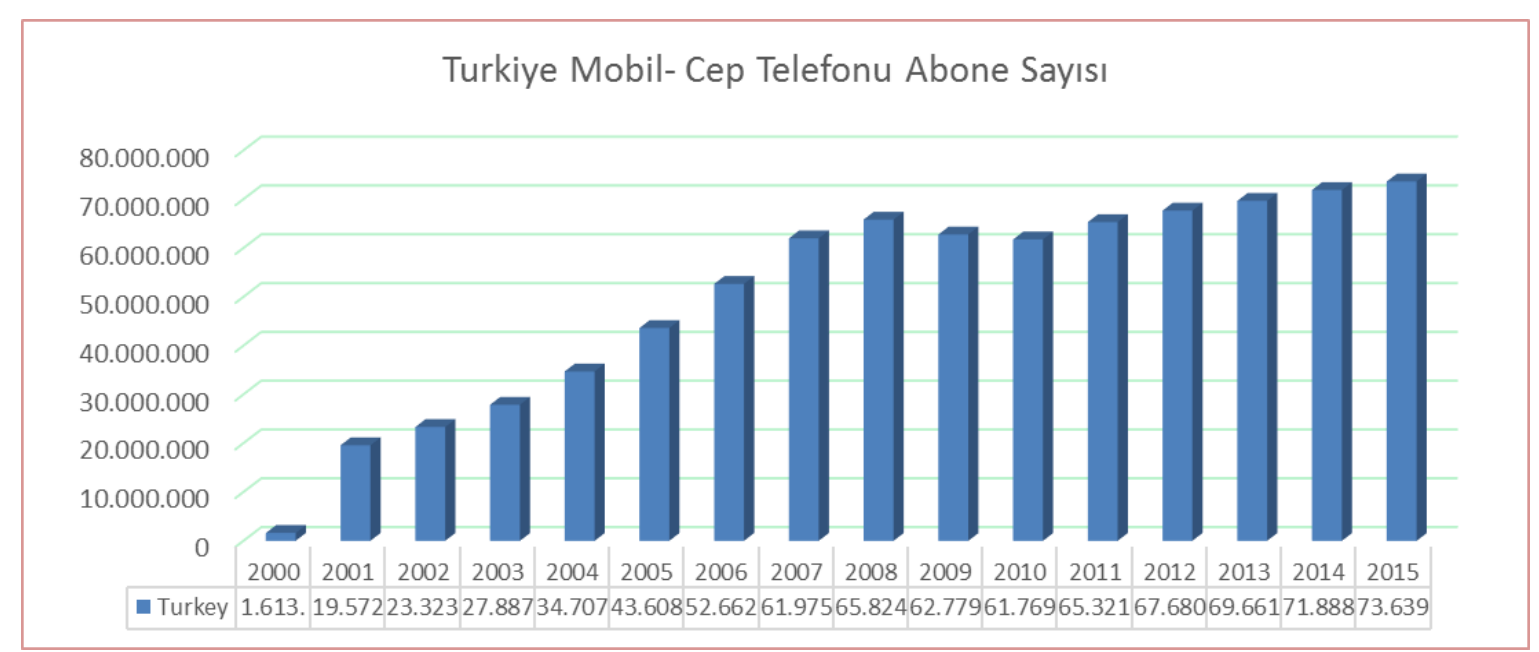

Kaynak: Uluslararası Telekominasyon Birliği- Mobile-Cellular Subscriotions: 2000-2015 arası dönem. http://www.itu.int/en/ITUD/Statistics/Pages/stat/default.aspx. Erişim Tarihi:11.04.2017

Cep telefonu pazarın 2000'li yıllardan sonra dünyanın en dinamik sektörlerinden biri olması sebebiyle dünyanın pek çok ülkesinde olduğu gibi Türkiye'de pek çok araştırmacı tarafından pek çok farklı tüketici grubu bağlamında araştırma konusu olduğu görülmektedir. Yaklaşık nüfusu kadar cep telefonu abone sayısına sahip olan Türkiye'de üniversite öğrencileri örnekleminde cep telefonu satın alma ve kullanma kriterleri (Gülmez, 2005), cep telefonu pazarında marka sadakati (Gölbaşı Şimşek ve Noyan, 2009), cep telefonu özelliklerini kullanımlarının ve gündelik iletişimlerine etkisi (Aydoğdu Karaarslan ve Budak,2012), cep telefonlarındaki mobil uygulamaları kabul ve kullanma durumları ( Uğur ve Turan, 2015), akıllı telefonlar ve marka değer algıları (Kuşku Özdemir ve Güzeloğlu, 2015), cep telefonu marka tercihleri (Çetin ve Alp, 2016; Yavuz ve Karabulut, 2016), literatürde yer alan çalışmalardır. 
Bu çalışma da, cep telefonları marka tercihlerini inceleyen diğer araştırmalar benzer nitelikte olup, tüketicilerin akıllı telefon markalarındaki marka değişimleri bir diğer tabirle marka geçişleri incelenmektedir. Celal Bayar Üniversitesi, Uygulamalı Bilimler Yüksekokulu 1. sınıf öğrencilerinin marka tercihlerini etkileyen faktörleri belirleyebilmek amacıyla bir alan araştırması yapılmıştır. Alan araştırması kapsamında öğrencilerin akıllı telefon kapsamındaki marka tercihleri ve varsa marka geçişlerini saptamak, bu yolla markaya olan sadakatinin olasılıklandırılması ve uzun dönemde tercih edilme oranlarının belirlenmesi amaçlanmıştır.

\section{LITERATÜR INCELEMESI}

Küreselleşen dünyada kendi ulusal pazarı başta olmak üzere uluslararası pazarlarda yer edinme, yerini koruma ve yayılmaya çalışan şirketler için en önemli aşama başlangıçta markalaşmayı başarabilmesinden geçmektedir. Bunun korunması için bilinen ve tercih edilen marka olmayı sağlamak daha önemli diğer adım olacaktır. Firmaların tüketicide yaratmak istediği marka sadakati Jacoby ve Chestnut'a (1978)' a göre aynı markanın bilinçli olarak tekrar tekrar satın alınmasın olarak tanımlanmaktadır. Aeker 'e (1999)' e göre ise marka sadakati satın alınılan markaya yönelik hem olumlu tutum hem de spesifik olarak tercih edilmeyi içinde barındırmaktadır. Gülmez ve Dörtyol (2009) marka sadakatini, tüketicilerin pazarda ihtiyaçlarını karşılayacak, benzer kalitede, özellikte ve hemen hemen aynı fiyatlarda başka markalar olmasına rağmen, uzun süreli olarak belirli bir markayı tercih etmedeki kararlı durumu olarak tanımlamaktadır. Markaların geliştirdiği tanıtma ve tutundurma faaliyetleri gibi stratejik çalışmalar müşterilerce tercih edilme oranlarında önemli yer tutmaktadır. Literatürde sıklıkla tüketici marka tercihleri üzerine pek çok çalışmaya rastlanmaktadır.

Mcclatchey (2006), Afrika'da üniversite öğrencilerin cep telefonu marka tercihlerinde etkili olan faktörün teknolojik imkânlar olduğunu tespit etmişlerdir. Gölbaşı Şimşek ve Noyan (2009), 770 üniversite öğrencisi örnekleminde cep telefonu pazarında memnuniyet, güven ve kalitenin marka sadakati üzerinde etkili olduğunu bulgulamışlardır. Ömürbek ve Şimşek (2012) üniversite öğrencilerinin cep telefonu marka tercihlerinde kullanım özelliklerinin en önemli kriter olduğu sonucuna ulaşmışlardır. Görece önemi en az olan özelliğin ise teknik özellik olduğu vurgulamışlardır. Yaşa ve Bozyiğit (2012), Mersin'deki iki üniversitede toplam 294 öğrenci örnekleminde cinsiyet ve gelir durumu ile cep telefonu tercihleri arasında ilişki olup olmadığını araştırmış, gelir durumu ile cep telefonu tercihleri arasında anlamlı ilişkinin olduğu sonucuna ulaşmışlardır.

Tatıı (2015), Bingöl Üniversite öğrencilerinin akıllı telefon seçimindeki belirleyiciler Akılı telefona bakış açılarının, gelir ve yaşları ile ilişkilendiren çalışmada, yaşın cep telefonu tercihlerinde önemli belirleyici olmadığı, gelirin etkili bir faktör olduğu tespit edilmiştir. Durmaz ve Şerbetçi (2016) Gaziantep Hasan Kalyoncu Üniversitesi ve Kahramanmaraş Sütçü İmam Üniversitesinde okuyan öğrencilerin cep telefonu tercihlerinde etken olan faktörleri tespit etmeyi hedefleyen çalışmada faktörleri kültürel, sosyal, kişisel ve psikolojik olarak sınıflandırmış, örneklemde $\% 48$ oranda Samsung marka cep telefonu tercih edildiğini, \%69 ile de öğrencilerin cep telefonu markasını önemli bulduğunu ortaya koymuşlarıdır. Bunun yanı sıra cep telefonun tercih edilme oranını, telefonun tasarımını, garantisini ve teknolojik özelliklerinin cep telefonu tercihlerinde önemli kriterler olduğunu belirtimişlerdir. Bu çalışmaların genel sonucu marka tercihleri ekonomik, psikolojik, sosyal ve demografik pek çok faktörden etkilenmektedir. Bu faktörler altındaki alt kriterler Tablo 1'de detaylandırılmıştır (Pride \& Ferrell,200:197 aktaran Bişkin, 2010: 421): Marka tercihi ve marka sadakati bilimsel araştırmalarda çokça çalışılmış, farklı açılardan birçok kez irdelenmiş bir konudur. Marka tercihinin konu edinen bazı çalışmalar Tablo 1'de verilmiştir.

Tablo 1: Tüketici Marka Kararlarını Etkileyen Bazı Faktörler

\begin{tabular}{|l|l|l|}
\hline $\begin{array}{l}\text { Marka Tercihini Etkileyen } \\
\text { Psikolojik Faktörler }\end{array}$ & $\begin{array}{l}\text { Marka Tercihini Etkileyen } \\
\text { Sosyal Faktörler }\end{array}$ & $\begin{array}{l}\text { Marka Tercihini Etkileyen } \\
\text { Demografik Faktörler }\end{array}$ \\
\hline *Gereksinme & • Aile & - Yaş \\
- Güdülenme & - Sosyal Sınıf & • Cinsiyet \\
- Algılama & • Danışma Grupları & • Eğitim ve Meslek \\
- Tutum ve İnançlar & • Kültür & • Gelir \\
- Öğrenme & & \\
- Kişilik & & \\
\hline
\end{tabular}

Kaynak: Pride \& Ferrell,2000: 197 aktaran Bişkin, 2010: 421. 


\section{Tablo 2: Marka Tercihleri Üzerine Yapılan Bazı Araştırmalar}

\begin{tabular}{|c|c|c|c|}
\hline $\begin{array}{l}\text { Yazar- } \\
\text { Çalışmanın Yılı }\end{array}$ & $\begin{array}{l}\text { Çalışmanın } \\
\text { konusu }\end{array}$ & Yöntem & Amaç \\
\hline $\begin{array}{l}\text { Çiftçi ve COP, } \\
2007\end{array}$ & $\begin{array}{l}\text { Kot } \\
\text { Pantolon } \\
\text { Marka } \\
\text { Tercihleri }\end{array}$ & $\begin{array}{l}\text { Faktör } \\
\text { Analizi. } \\
\text { Tek Faktörlü, } \\
\text { Varyans } \\
\text { Analizi }\end{array}$ & $\begin{array}{l}\text { Üniversite öğrencilerinin sahip oldukları bazı } \\
\text { demografik özelliklerine göre, kot } \\
\text { pantolon marka tercihlerinin farklılaşıp } \\
\text { farklılaşmadı̆ı incelenmiştir }\end{array}$ \\
\hline $\begin{array}{l}\text { Alp ve Öz, } \\
2009\end{array}$ & $\begin{array}{l}\text { Taşınabilir } \\
\text { Bilgisayar } \\
\text { Marka } \\
\text { Tercihleri }\end{array}$ & $\begin{array}{l}\text { Markov } \\
\text { Zincirleri }\end{array}$ & $\begin{array}{l}\text { Taşınır Bilgisayar Markaları için gelecekteki } \\
\text { pazar paylarının tahmin edilmesi }\end{array}$ \\
\hline $\begin{array}{l}\text { Ömürbek ve } \\
\text { Şimşek, } 2012\end{array}$ & $\begin{array}{l}\text { Cep Telefonları } \\
\text { tercihleri }\end{array}$ & AHP & $\begin{array}{lcc}\text { Süleyman } & \text { Demirel } & \text { Üniversitesi } \\
\text { öğrencilerinin } & \text { cep telefonları tercihlerinin } \\
\text { belirlenmesi } & & \end{array}$ \\
\hline $\begin{array}{l}\text { Arıtan ve } \\
\text { Akyüz, } 2015\end{array}$ & $\begin{array}{l}\text { Otomobil } \\
\text { Marka } \\
\text { tercihleri }\end{array}$ & $\begin{array}{l}\text { Markov } \\
\text { Zinciri }\end{array}$ & $\begin{array}{l}\text { Tüketicilerin otomobil markalarına olan } \\
\text { marka sadakatlerinin tespit edilmesini ve } \\
\text { tüketicilerin ileriki dönemlerdeki marka } \\
\text { tercihlerinin öngörülmesi }\end{array}$ \\
\hline Soykan, 2015 & $\begin{array}{l}\text { Otomobil } \\
\text { lastiği marka } \\
\text { tercihleri }\end{array}$ & $\begin{array}{l}\text { Markov } \\
\text { Zinciri }\end{array}$ & $\begin{array}{l}\text { Otomobil lastiği markalarının uzun dönem } \\
\text { pazar payının tahminlemesi }\end{array}$ \\
\hline $\begin{array}{l}\text { Çetin ve Alp, } \\
2016\end{array}$ & $\begin{array}{l}\text { Cep Telefonları } \\
\text { Marka } \\
\text { Tercihleri }\end{array}$ & $\begin{array}{l}\text { Markov } \\
\text { Zinciri }\end{array}$ & $\begin{array}{l}\text { Yıldız Teknik Üniversitesi öğrencileri } \\
\text { örnekleminde cep telefonları } \\
\text { Markaların cinsiyete göre tercih geçişleri }\end{array}$ \\
\hline $\begin{array}{ll}\text { Şentürk } & \text { ve } \\
\text { Alp, } 2016 & \end{array}$ & $\begin{array}{l}\text { Mobil Operatör } \\
\text { ve Internet } \\
\text { Servis } \\
\text { Sağlayıcısı } \\
\text { marka } \\
\text { tercihleri }\end{array}$ & $\begin{array}{l}\text { Markov } \\
\text { Zincirleri }\end{array}$ & $\begin{array}{l}\text { Hem mobil operatör hem de internet } \\
\text { servisini aynı anda sunan tek marka } \\
\text { şeklindeki } 12 \text { Türk firmasının tercihleri için } \\
\text { durum analizi }\end{array}$ \\
\hline $\begin{array}{ll}\text { Yavuz } & \text { ve } \\
\text { Karabulut, } & \\
2016 & \end{array}$ & $\begin{array}{l}\text { Cep telefonu } \\
\text { marka } \\
\text { tercihleri }\end{array}$ & $\begin{array}{l}\text { Markov } \\
\text { Zincirleri }\end{array}$ & $\begin{array}{lll}\text { Erzincan } & \text { Üniversitesi } & \text { öğrencileri } \\
\text { örnekleminde cep telefonları } & \text { Markaları } \\
\text { cinsiyete göre tercih geçişleri } & \end{array}$ \\
\hline
\end{tabular}

Sonuç

Öğrencilerin marka kimliği, cinsiyet, bölüm, fakülte bazında farkı eğilimler gösterdiği sonucuna ulaşılmıştır.

Aynı marka taşınabilir bilgisayarı tekrar tercih olasılıkları sırasıyla Sony (\%37,49), Arçelik (\%33,34), MSI (33,32), Apple (\%33,30), HP $(\% 31,26)$ ve Dell $(\% 30,44)$ olduğu görülmüştür. Kullanıııların taşınabilir bilgisayar tercihlerinde uzun dönemde herhangi bir dışsal etki olmadığı durumda, gelecekte kullanıııların \%23,10’u HP, \%14,97'si Sony, \%14,81'i Toshiba, \%8,60'ı Acer, \%7,61'i IBM ve \%6,52'si Dell marka taşınabilir bilgisayar kullanıyor olacağı yorumlanmıştır.

Cep telefonu tercih kriterleri: görsel özellikler, teknik özellikler, marka özellikleri ve kullanım özellikleri olarak belirlenmiştir. . En iyi cep telefonu modelinde Nokia $(0,309)$, LG $(0,179)$, Samsung $(0,079)$ ve diğerleri $(0,433)$ olarak belirlenmiştir.

Katılımcıların en yüksek marka bağlıı̆ı̆ını AUDi, MERCEDES ve OPEL markaların gösterdikleri bulunmuștur. Bayan katılımcılar başta VOLKSWAGEN (VW), RENAULT ve PEUGEOT olmak üzere markaları tercih ederlerken, erkek katılımcılar ise başlıca TOFAŞ, RENAULT, FiAT ve FORD markalarını tercih etmektedirler. Düşük gelirli katılımcılar en fazla TOFAŞ ve RENAULT markalarını, orta gelir grubundakiler en fazla TOFAŞ, RENAULT ve FIAT ve FORD markalarını, üst gelir grubundakiler ise VW, TOYOTA, SKODA, OPEL, NISSAN, HONDA ve CITROEN markalarını tercih etmektedir

2 yıllık periyodlar ile 2010-2020 yılları arası otomobil lastikleri markalarının pazar payları tahminleri elde edilmiştir

Marka bağılıkları, diğer bir ifade ile kullanıııların aynı marka cep telefonunu tekrar tercih olasılıkları sırasıyla Iphone (\%86.6), Sony (\%53.6), Samsung (\%46.8), LG (\%33,30), HTC (\%26.2), Turkcell (\%20.0), Nokia (\%14.9) ve General Mobile (\%14.3) olduğu görülmektedir. Kullanıcıların cep telefonu tercihlerinde uzun dönemde herhangi bir dışsal etki olmadığı durumda, gelecekte \%66.67'si phone, \%17.91'i Samsung, \%5.88'i Sony, \%3.55'i LG, \%1.82'si HTC, \%1.70'i Nokia, \%1.08'i General Mobile, \%0.60' । Blackberry, \%0.47'si Turkcell, \%0.13'ü Vestel, \%0.13'ü Huawei, \%0.03'ü Philips, \%0.01'i Vodafone, \%0.01'i Motorola, \%0.01'i Siemens marka cep telefonu kullanıyor olacağı belirtilmiştir.

Aynı firmaya ait geçişlerin ne yönde değiştiğini gözlemlemek için ilk durumdaki geçiş olasılıkları matrisi incelendiğinde abonelerin Aveatnet kullanıcılarının \%0,93, Vodafone- Vodafone Net kullanıcılarının \%0,03 arttığı, Turkcell-Superonline kullanıııarının oranının ise $\%, 22$ azaldığı bulgulanmıştır.

Mevcut durumda en fazla kullanılan ilk üç cep telefonu markasının sırasıyla Samsung $(\% 43,5)$, Apple $(\% 15,2)$ ve LG(\%10,8) olduğu elirlenmiştir. Bu markaları kullanan öğrenciler, aynı zamanda bu markalara sadık da kalmışlardır. Kız öğrencilerde sadık olunan marka sıralaması Apple (\%70), Samsung (\%51) ve LG (\%22) olarak gerçekleşirken, erkek öğrenciler için bu durum Apple (\%47), Samsung (\%45) ve LG (\%30) olarak gerçekleşmiştir. Kız-erkek öğrenci ayııımı yapılmaksızın genel olarak sadık olunan marka sıralaması ise Apple (\%55), Samsung (\%49) ve LG (\%26) olarak gerçekleşmiştir. 


\section{YÖNTEM}

Tablo 2'de görüldüğü üzere marka tercihlerini araştıran pek çok araştırma yöntem olarak Markov zincirleri analizini tercih etmişlerdir. Markov zincirleri ve genel olarak analiz yöntemine verilen ad Markov süreçleri, Rus matematikçi Andrei Andreevich Markov (1856-1922) tarafından literatüre kazandırılmıştır ( Önalan, 2010: 49).

Markov zincirleri analizi, rastgele sonuçlar doğuran bir olay serisi olan stokastik süreçlerden birisidir. Literatürde Markov zincirleri analizi meteroloji (Koçak ve Şen, 1998), şüpheli alacak zararlarının büyüklüklerinin hesaplanması ( Gürbüz \& Köse,2002), işletmelerin tahminleme sorunları (Özdemir \& Gümüşoğlu; 2007), altın fiyatları dağılımları (Özdağoğlu vd. 2012), hisse senedi fiyat hareketleri ( IIlarslan, 2014; Özdemir \& Demireli, 2014), işletme performans hedeflerine ulaşma durum tahmini (Öztemiz, 2016), marka tercihleri ( Alp ve Öz, 2009; Arıtan ve Akyüz, 2015; Soykan, 2015; Çetin ve Alp, 2016; Şentürk ve Alp, 2016; Yavuz ve Karabulut, 2016), olmak üzere pek çok alanda uygulama alanına sahiptir.

$\mathrm{S}=\left\{\mathrm{t}_{\mathrm{i}}: \quad \mathrm{i}=0,1,2,3, \ldots ..\right\}$ durum uzayı olmak üzere ve $i \in S$ için $X_{t_{i}}$, i durumun olasılığı olmak üzere, $X_{t_{n}}$ 'nin $\left(X_{t_{1}}, X_{t_{2}}, \ldots \ldots, X_{t_{n-1}}\right)$ 'in değerlerine göre koşullu olasılık dağılımının sadece $X_{t_{n-1}}$ 'in değerine bağı ise $\left(X_{t}: \mathrm{T}\right)$ stokastik sürecine Markov süreci adı verilmektedir. Markov süreci, $\mathrm{P}=\left\{X_{t_{n}}=X_{n} \mid X_{t_{n-1}}=X_{n-1}, \ldots, X_{t_{1}}=X_{1}\right\}$ ile gösterilebilir. Yani Ching vd.(2002) Markov sürecinin bir nevi bir durumunun sistemdeki tüm olası durumlarının listesi olduğundan bahsetmektedir. Markov zinciri ise geçmişteki ve şimdiki faaliyetlerden yararlanarak bir durumun gelecekteki olasılıklarını belirlemek üzerine kuruludur ( Büyüktatlı vd. ,2013: 2).

Matematiksel olarak Markov zinciri S durum uzayı için,

$$
\mathrm{P}=\left\{X_{t+1}=i \mid X_{t}=j\right\}=p_{i j} \quad, \mathrm{i}, \mathrm{j} \in S
$$

olmak üzere t zamanında j. durumda olan sürecin t+1 zamanında i durumunda olma olasılığı olan $p_{i j}$ 'leri geçiş olasılığı kabul eden, geçiş olasılıkları ile oluşan $\mathrm{P}_{\mathrm{ij}}=\left[p_{i j}\right]$ geçiş olasılığı matrisi yardımıyla verilen bir durumda iken gelecekte bir durumda bulunmanın koşullu olasılığı elde eden stokastik bir süreçtir. Geçiş olasılıkları iki eşitlik sağlanmalıdır: i,j $\in S$ için

$$
\begin{gathered}
0 \leq p_{i j} \leq 1 \\
\sum_{j=0}^{\infty} p_{i j}=1 .
\end{gathered}
$$

Olasılıklar durum olasılıklarıdır, $p_{i j}$ geçiş olasılıklarının zamana bağlı olarak bir sayıya yakınsaması yani limitinin olması ve $\mathrm{P}_{\mathrm{ij}}=\left[p_{i j}\right]$ geçiş olasılığı matrisinde tüm vektörlerin eşit olması durumu söz konusudur (Alp ve Öz, 2009:10). Analizde herhangi bir zamanda $\mathrm{P}_{\mathrm{ij}}=\left[p_{i j}\right]$ geçiş olasılığı matrisinin tüm vektörlerinin eşit olma durumuna elde edilen matrise kararlı durum olasılık matrisi denir. Can (2006), her $\mathrm{i}, \mathrm{j} \in S$ durum uzayı için, $\mathrm{n}=0,1,2, \ldots$ olmak üzere,

$$
\mathrm{P}\left\{X_{n+1}=i \mid X_{n}=j\right\}=\mathrm{P}\left\{X_{1}=i \mid X_{0}=j\right\}=p_{i j}
$$

eşitliği durumunda geçiş olasılıklarının zamandan bağımsız olduğunu, geçiş olasılıklarının zamandan bağımsız olarak homojenleştiğini bu durumun istenen kararlı durum olduğunu belirtmiştir. Bu kararlı duruma denge durumu matrisi ismi de verilmektedir. Bu $\mathrm{P}_{\mathrm{ij}}=\left[p_{i j}\right]$ denge durum matrisinin vektörlerinin her biri birbirine eşittir ve bunlara da denge durum vektörü ismi verilmektedir. Yani matematiksel olarak gösterirsek, $\mathrm{P}_{\mathrm{ij}}=\left[p_{i j}\right]$ denge durum matrisinin bir vektörü $\mathrm{V}$ $=\left[\begin{array}{llll}v_{1} & v_{2} & \ldots & v_{n}\end{array}\right]$ olmak üzere $\lim _{n \rightarrow \infty} P_{i j}=V$ ve $\sum_{i=1}^{n} v_{i}=1$ olmalıdır.

Buradaki denge durum vektörü,

$$
V \cdot P=V
$$

olacak şekilde geçiş olasılık vektörleri yardımıyla kolaylıkla hesaplanabilir (Ergeç, 1996:134).

\section{BULGULAR VE TARTIŞMA}

Bu çalışmada akıllı telefon marka tercihlerinin belirlenmesi için Celal Bayar Üniversitesi Uygulamalı Bilimler Yüksekokulu Uluslararası Ticaret bölümü ve Bankacılık ve Finans bölümü birinci sınıf 200 öğrenciye anket uygulanmıştır. Bu anketlerden 153 âdetinin kullanılabilir olduğu, kalanının ise eksik veri sebebiyle uygulama dışı olduğu görülmüştür. Yapılan analizde 1. sınıf öğrencilerin akıllı telefon markaları arasından tercih ettikleri; LG, Nokia, Samsung, Iphone, General Mobile (GM), Turkcell, Sony, HTC, Asus ve Casper olmak üzere toplamda 10 marka üzerine yoğunlaştıkları tespit edilmiştir.

Ankette öğrencilere toplamda 2 soru sorulmuştur. Öğrencilere sorulan ikinci soru "Bir önce kullandığınız akıllı telefon markası nedir ?" sorusudur. Bu soruya verilen yanıtlar sayesinde öğrencilerin önceki kullandıkları telefon markaları arasında \%47 ile Samsung liderliğini korurken, bunu \% 18 ile Nokia, \% 15,6 ile İphone ve \% 6, 5 ile Sony takip etmektedir. Öğrencilerin kullandıkları bir önceki cep telefonu markaları ve oranları Tablo 3'de verilmiştir. 
Tablo 3: Bir Önceki Cep Telefonu Markaları ve Oranları

\begin{tabular}{|c|c|c|c|}
\hline Cep Telefon Markaları & Kullanan SayıSI & Oranlar & \% \\
\hline SAMSUNG & $\mathbf{7 2}$ & $\mathbf{0 , 4 7 0 6}$ & $\mathbf{4 7}$ \\
\hline NOKIA & $\mathbf{2 7}$ & $\mathbf{0 , 1 7 6 5}$ & $\mathbf{1 5 , 6}$ \\
\hline iPHONE & $\mathbf{2 4}$ & $\mathbf{0 , 1 5 6 9}$ & $\mathbf{6 , 5}$ \\
\hline SONY & $\mathbf{1 0}$ & $\mathbf{0 , 0 6 5 4}$ & 3,9 \\
\hline LG & 6 & 0,0392 & 3,3 \\
\hline GM & 5 & 0,0327 & 1,9 \\
\hline TURKCELL & 3 & 0,0196 & 1,9 \\
\hline HTC & 3 & 0,0196 & 1,3 \\
\hline CASPER & 2 & 0,0131 & 0,6 \\
\hline ASUS & 1 & 0,0065 & $\mathbf{1 0 0}$ \\
\hline TOPLAM & 153 & 1 & \\
\hline
\end{tabular}

Öğrencilere uygulanan ankette ilk soru 'Şuanda kullanmakta olduğunuz akıllı telefon markası nedir?” olup, bu dönemde bu 10 akıllı telefon markası arasında \%32 ile Samsung, \%27 ile İphone, \%12,4 ile LG ve \%8,4 ile GM kullanıldığı sonucuna ulaşılmıştır. Şuanda kullanmakta oldukları telefon markaları ve oranları Tablo 4'de gösterilmiştir.

Tablo 4. Şuanda Kullanmakta Oldukları Telefon Markaları ve Oranları

\begin{tabular}{|c|c|c|c|}
\hline Cep Telefon Markaları & Kullanan SayısI & Oranlar & $\mathbf{\%}$ \\
\hline SAMSUNG & $\mathbf{4 9}$ & $\mathbf{0 , 3 2 0 2 6 1}$ & $\mathbf{3 2}$ \\
\hline IPHONE & $\mathbf{4 1}$ & $\mathbf{0 , 2 6 7 9 7 4}$ & $\mathbf{1 2 , 4}$ \\
\hline LG & $\mathbf{1 9}$ & $\mathbf{0 , 1 2 4 1 8 3}$ & $\mathbf{8 , 4}$ \\
\hline GM & $\mathbf{1 3}$ & $\mathbf{0 , 0 8 4 9 6 7}$ & 5,8 \\
\hline SONY & 9 & 0,058824 & 5,2 \\
\hline HTC & 8 & 0,052288 & 3,9 \\
\hline ASUS & 6 & 0,039216 & 2 \\
\hline TURKCELL & 3 & 0,019608 & 2 \\
\hline CASPER & 3 & 0,019608 & 1,3 \\
\hline NOKIA & 2 & 0,013072 & 100 \\
\hline TOPLAM & 153 & 1 & \\
\hline
\end{tabular}

Önceki kullanımda liderliğini koruyan Samsung marka cep telefon tercihleri şuan ki kullanımda yine lider olmasına rağmen \%15 gibi ciddi bir oranda düşmüş, tam aksine önceki kullanımda \% 15,6 olan İphone \%12 pay kazanmıştır. (Bakınız Tablo 4). Önceki kullanıma göre en çok terk edilen telefon markası Nokia olmuştur. Önceki kullanımda \% 18 oranla ikinci sırada yer alan Nokia marka telefonların kullanım oranı şuan ki durumda \% 1,3' e kadar gerilemiştir (Bakınız Tablo 3). Turkcell pay kaybetmeyen telefon markası olurken, HTC 'de \% 3,2'lik bir artış söz konusudur. \% 6,5 ile en çok tercih edilenler sırasında dördüncü olan Sony'nin yerini şuan ki kullanımda \%12,4 ile LG ve \%8,4 ile GM marka cep telefonları almıştır. Bu tercihlerden yolla çıkılarak oluşturulan Geçiş Diyagramı Tablo 5'de verilmiştir.

Tablo 5: Önceki Markadan Şuan ki Markaya Geçiş Diyagramı

\begin{tabular}{|c|c|c|c|c|c|c|c|c|c|c|c|c|}
\hline & LG & NOKIA & SAMSUNG & IPHONE & GM & TURKCELL & SONY & HTC & ASUS & CASPER & ÖNCEKI & Önceki \% \\
\hline LG & 1 & 0 & 1 & 2 & 0 & 0 & 1 & 0 & 0 & 1 & 6 & 3,9 \\
\hline NOKIA & 3 & 0 & 19 & 0 & 0 & 2 & 1 & 1 & 1 & 0 & 27 & 18 \\
\hline SAMSUNG & 10 & 2 & 18 & 19 & 9 & 0 & 5 & 6 & 2 & 1 & 72 & 47 \\
\hline IPHONE & 1 & 0 & 5 & 18 & 0 & 0 & 0 & 0 & 0 & 0 & 24 & 15,6 \\
\hline GM & 1 & 0 & 2 & 1 & 0 & 0 & 1 & 0 & 0 & 0 & 5 & 3,3 \\
\hline TURKCELL & 1 & 0 & 0 & 0 & 2 & 0 & 0 & 0 & 0 & 0 & 3 & 1,9 \\
\hline SONY & 1 & 0 & 2 & 1 & 1 & 1 & 1 & 1 & 2 & 0 & 10 & 6,5 \\
\hline HTC & 1 & 0 & 1 & 0 & 0 & 0 & 0 & 0 & 1 & 0 & 3 & 1,9 \\
\hline ASUS & 0 & 0 & 0 & 0 & 0 & 0 & 0 & 0 & 0 & 1 & 1 & 0,6 \\
\hline
\end{tabular}




\begin{tabular}{|c|c|c|c|c|c|c|c|c|c|c|c|c|}
\hline CASPER & 0 & 0 & 1 & 0 & 1 & 0 & 0 & 0 & 0 & 0 & 2 & 1,3 \\
\hline ŞUANKi & 19 & 2 & 49 & 41 & 13 & 3 & 9 & 8 & 6 & 3 & 153 & \\
\hline Şuanki \% & 12,4 & 1,3 & 32 & 27 & 8,4 & 2 & 5,8 & 5,2 & 3,9 & 2 & $100 \%$ & $100 \%$ \\
\hline
\end{tabular}

Tablo 5'te öğrencilerin önceki akıllı telefon markalarından şuan ki akıllı telefon markalarına geçişleri sayılarak oluşturulan geçiş diyagramı gösterilmiştir. Tablo 1'de gösterilen geçiş diyagramından yararlanılarak oluşturulan geçiş olasılıkları matrisi için satırların her bir hücresindeki sayı ilgili satırın toplam büyüklüğüne bölünmüştür. Bu şekilde oluşturulan Markov zinciri geçiş olasılıkları matrisi Tablo 6'daki gibi hesaplanmıştır.

Tablo 6: Markadan Markaya Geçiş Olasılıkları Matrisi

$\mathbf{P}=\left|\begin{array}{llllllllll}0,17 & 0,00 & 0,17 & 0,33 & 0,00 & 0,00 & 0,17 & 0,00 & 0,00 & 0,17 \\ 0,11 & 0,00 & 0,70 & 0,00 & 0,00 & 0,07 & 0,04 & 0,04 & 0,04 & 0,00 \\ 0,14 & 0,03 & 0,25 & 0,26 & 0,13 & 0,00 & 0,07 & 0,08 & 0,03 & 0,01 \\ 0,04 & 0,00 & 0,21 & 0,75 & 0,00 & 0,00 & 0,00 & 0,00 & 0,00 & 0,00 \\ 0,20 & 0,00 & 0,40 & 0,20 & 0,00 & 0,00 & 0,20 & 0,00 & 0,00 & 0,00 \\ 0,33 & 0,00 & 0,00 & 0,00 & 0,67 & 0,00 & 0,00 & 0,00 & 0,00 & 0,00 \\ 0,10 & 0,00 & 0,20 & 0,10 & 0,10 & 0,10 & 0,10 & 0,10 & 0,20 & 0,00 \\ 0,33 & 0,00 & 0,33 & 0,00 & 0,00 & 0,00 & 0,00 & 0,00 & 0,33 & 0,00 \\ 0,00 & 0,00 & 0,00 & 0,00 & 0,00 & 0,00 & 0,00 & 0,00 & 0,00 & 1,00 \\ 0,00 & 0,00 & 0,50 & 0,00 & 0,50 & 0,00 & 0,00 & 0,00 & 0,00 & 0,00\end{array}\right|$

Burada belirtilmesi gereken bir diğer özellikte markaya olan bağımlıkları gösteren geçiş olasılıkları matrisinin köşegen elemanlarının değerleridir ( Alp ve Öz, 2009: 46). Tablo 2'de yer alan geçiş olasılıkları matrisinde yer alan ve 0'dan farklı değer alan markalar Tablo 7' de gösterilmiştir.

Tablo 7: Akılı Telefon Marka Bağımlıkları

\begin{tabular}{|c|c|}
\hline Akıllı Telefon Markaları & Marka Bağımlıkları \% \\
\hline LG & 17 \\
\hline SAMSUNG & 25 \\
\hline iPHONE & 75 \\
\hline SONY & 10 \\
\hline
\end{tabular}

Markov zinciri analizinde amaç uzun dönemde meydana gelecek durumların olasılıkları gösteren denge durum ya da kararlı durum matrisine ulaşmaktır. $\mathrm{P}$ geçiş matrisinin $\mathrm{n}$. adım geçiş olasılıklarının hesaplanması için kullanılan yöntem ChapmanKolmogrov yardımıyla Microsoft Excel'de basit DÇARP komutu olan matris çarpımı ile oluşturulan $i=1,2,3, \ldots n$ adım geçiş matrisleri Tablo 8 altında derlenmiştir. Denge durum olasılığı $n=12$. adımda meydana gelmiştir.

Tablo 8: N Adım Geçiş Olasılıkları Matrisler

\begin{tabular}{|c|c|c|c|c|c|c|c|c|c|c|c|c|c|c|c|c|c|c|c|c|}
\hline 0,08 & 0,00 & 0,26 & 0,37 & 0,12 & 0,02 & 0,06 & 0,03 & 0,04 & 0,03 & \multirow{10}{*}{$\mathbf{P}^{3}=$} & 0,11 & 0,01 & 0,24 & 0,40 & 0,06 & 0,01 & 0,06 & 0,03 & 0,03 & 0,06 \\
\hline 0,16 & 0,02 & 0,21 & 0,23 & 0,14 & 0,00 & 0,07 & 0,06 & 0,04 & 0,07 & & 0,12 & 0,01 & 0,26 & 0,31 & 0,07 & 0,01 & 0,08 & 0,03 & 0,04 & 0,07 \\
\hline 0,13 & 0,01 & 0,26 & 0,34 & 0,05 & 0,01 & 0,07 & 0,03 & 0,05 & 0,05 & & 0,10 & 0,01 & 0,23 & 0,39 & 0,07 & 0,01 & 0,06 & 0,03 & 0,03 & 0,08 \\
\hline 0,07 & 0,01 & 0,22 & 0,63 & 0,03 & 0,00 & 0,02 & 0,02 & 0,01 & 0,01 & & 0,08 & 0,01 & 0,23 & 0,56 & 0,03 & 0,00 & 0,03 & 0,02 & 0,02 & 0,02 \\
\hline 0,12 & 0,01 & 0,22 & 0,34 & 0,07 & 0,02 & 0,08 & 0,05 & 0,05 & 0,04 & & 0,11 & 0,01 & 0,23 & 0,37 & 0,07 & 0,01 & 0,06 & 0,03 & 0,04 & 0,07 \\
\hline 0,19 & 0,00 & 0,32 & 0,24 & 0,00 & 0,00 & 0,19 & 0,00 & 0,00 & 0,06 & & 0,11 & 0,01 & 0,23 & 0,35 & 0,09 & 0,02 & 0,07 & 0,05 & 0,05 & 0,04 \\
\hline 0,15 & 0,01 & 0,18 & 0,19 & 0,10 & 0,01 & 0,06 & 0,03 & 0,06 & 0,22 & & 0,10 & 0,01 & 0,28 & 0,27 & 0,15 & 0,01 & 0,06 & 0,02 & 0,03 & 0,09 \\
\hline 0,10 & 0,01 & 0,14 & 0,20 & 0,04 & 0,00 & 0,08 & 0,03 & 0,01 & 0,39 & & 0,07 & 0,00 & 0,34 & 0,24 & 0,22 & 0,01 & 0,04 & 0,02 & 0,03 & 0,03 \\
\hline 0,00 & 0,00 & 0,50 & 0,00 & 0,50 & 0,00 & 0,00 & 0,00 & 0,00 & 0,00 & & 0,17 & 0,01 & 0,33 & 0,23 & 0,06 & 0,00 & 0,13 & 0,04 & 0,01 & 0,01 \\
\hline 0,17 & 0,01 & 0,33 & 0,23 & 0,06 & 0,00 & 0,13 & 0,04 & 0,01 & 0,01 & & 0,12 & 0,01 & 0,24 & 0,34 & 0,06 & 0,01 & 0,08 & 0,04 & 0,05 & 0,05 \\
\hline 0,10 & 0,01 & 0,24 & 0,42 & 0,07 & 0,01 & 0,05 & 0,03 & 0,03 & 0,05 & & 0,10 & 0,01 & 0,24 & 0,43 & 0,07 & 0,01 & 0,05 & 0,03 & 0,03 & 0,05 \\
\hline
\end{tabular}


$\begin{array}{|llllllllll|}0,10 & 0,01 & 0,24 & 0,37 & 0,08 & 0,01 & 0,06 & 0,03 & 0,03 & 0,07\end{array}$ $\begin{array}{lllllllllll}0,10 & 0,01 & 0,25 & 0,40 & 0,08 & 0,01 & 0,05 & 0,03 & 0,03 & 0,05\end{array}$ $\begin{array}{lllllllllll}0,09 & 0,01 & 0,23 & 0,52 & 0,04 & 0,00 & 0,04 & 0,02 & 0,02 & 0,03\end{array}$

$\mathbf{P}^{4}=\mid \begin{array}{llllllllll}0,10 & 0,01 & 0,24 & 0,40 & 0,08 & 0,01 & 0,05 & 0,03 & 0,03 & 0,06 \\ 0,11 & 0,01 & 0,24 & 0,38 & 0,07 & 0,01 & 0,06 & 0,03 & 0,04 & 0,07\end{array}$ $\begin{array}{lllllllllll}0,11 & 0,01 & 0,24 & 0,38 & 0,07 & 0,01 & 0,06 & 0,03 & 0,04 & 0,07\end{array}$ $\begin{array}{lllllllllll}0,11 & 0,01 & 0,27 & 0,34 & 0,09 & 0,01 & 0,07 & 0,03 & 0,03 & 0,05\end{array}$ $\begin{array}{lllllllllll}0,13 & 0,01 & 0,27 & 0,34 & 0,07 & 0,00 & 0,08 & 0,03 & 0,02 & 0,05\end{array}$ $\begin{array}{lllllllllll}0,12 & 0,01 & 0,24 & 0,34 & 0,06 & 0,01 & 0,08 & 0,04 & 0,05 & 0,05\end{array}$ $\left|\begin{array}{lllllllllll}0,11 & 0,01 & 0,23 & 0,38 & 0,07 & 0,01 & 0,06 & 0,03 & 0,04 & 0,07\end{array}\right|$

$\begin{array}{|llllllllll|}0,10 & 0,01 & 0,24 & 0,44 & 0,06 & 0,01 & 0,05 & 0,03 & 0,03 & 0,05\end{array}$ $\begin{array}{llllllllll}0,10 & 0,01 & 0,24 & 0,42 & 0,07 & 0,01 & 0,06 & 0,03 & 0,03 & 0,05\end{array}$ $\begin{array}{lllllllllll}0,10 & 0,01 & 0,24 & 0,43 & 0,06 & 0,01 & 0,05 & 0,03 & 0,03 & 0,05\end{array}$ $\begin{array}{lllllllllll}0,09 & 0,01 & 0,24 & 0,47 & 0,06 & 0,00 & 0,05 & 0,02 & 0,02 & 0,04\end{array}$ $\begin{array}{llllllllll}0,10 & 0,01 & 0,24 & 0,43 & 0,06 & 0,01 & 0,05 & 0,03 & 0,03 & 0,05\end{array}$

$\mathbf{P}^{6}=\mid \begin{array}{llllllllll}0,10 & 0,01 & 0,24 & 0,42 & 0,07 & 0,01 & 0,05 & 0,03 & 0,03 & 0,05 \\ 0,10 & 0,01 & 0,24 & 0,41 & 0,07 & 0,01 & 0,06 & 0,03 & 0,03 & 0,05\end{array}$ $\begin{array}{lllllllllll}0,10 & 0,01 & 0,24 & 0,41 & 0,07 & 0,01 & 0,06 & 0,03 & 0,03 & 0,05\end{array}$ $\begin{array}{lllllllllll}0,10 & 0,01 & 0,24 & 0,41 & 0,07 & 0,01 & 0,05 & 0,03 & 0,03 & 0,06\end{array}$ $\begin{array}{lllllllllll}0,10 & 0,01 & 0,25 & 0,40 & 0,08 & 0,01 & 0,05 & 0,03 & 0,03 & 0,06\end{array}$ $\begin{array}{llllllllll}0,10 & 0,01 & 0,24 & 0,42 & 0,07 & 0,01 & 0,05 & 0,03 & 0,03 & 0,05\end{array}$

$\begin{array}{|llllllllll|}0,10 & 0,01 & 0,24 & 0,44 & 0,06 & 0,01 & 0,05 & 0,03 & 0,03 & 0,05\end{array}$ $\begin{array}{llllllllll}0,10 & 0,01 & 0,24 & 0,44 & 0,06 & 0,01 & 0,05 & 0,03 & 0,03 & 0,05\end{array}$ $\begin{array}{lllllllllll}0,10 & 0,01 & 0,24 & 0,44 & 0,06 & 0,01 & 0,05 & 0,03 & 0,03 & 0,05\end{array}$ $\begin{array}{lllllllllll}0,09 & 0,01 & 0,24 & 0,46 & 0,06 & 0,01 & 0,05 & 0,02 & 0,02 & 0,04\end{array}$ $\mathbf{P}^{\mathbf{8}}=$ $\begin{array}{llllllllll}0,10 & 0,01 & 0,24 & 0,44 & 0,06 & 0,01 & 0,05 & 0,03 & 0,03 & 0,05 \\ 0,10 & 0,01 & 0,24 & 0,44 & 0,06 & 0,01 & 0,05 & 0,03 & 0,03 & 0,05\end{array}$ $\begin{array}{llllllllll}0,10 & 0,01 & 0,24 & 0,43 & 0,06 & 0,01 & 0,05 & 0,03 & 0,03 & 0,05\end{array}$ $\begin{array}{llllllllll}0,10 & 0,01 & 0,24 & 0,43 & 0,06 & 0,01 & 0,05 & 0,03 & 0,03 & 0,05\end{array}$ $\begin{array}{llllllllll}0,10 & 0,01 & 0,24 & 0,43 & 0,06 & 0,01 & 0,05 & 0,03 & 0,03 & 0,05\end{array}$ $\left|\begin{array}{llllllllll}0,10 & 0,01 & 0,24 & 0,44 & 0,06 & 0,01 & 0,05 & 0,03 & 0,03 & 0,05\end{array}\right|$

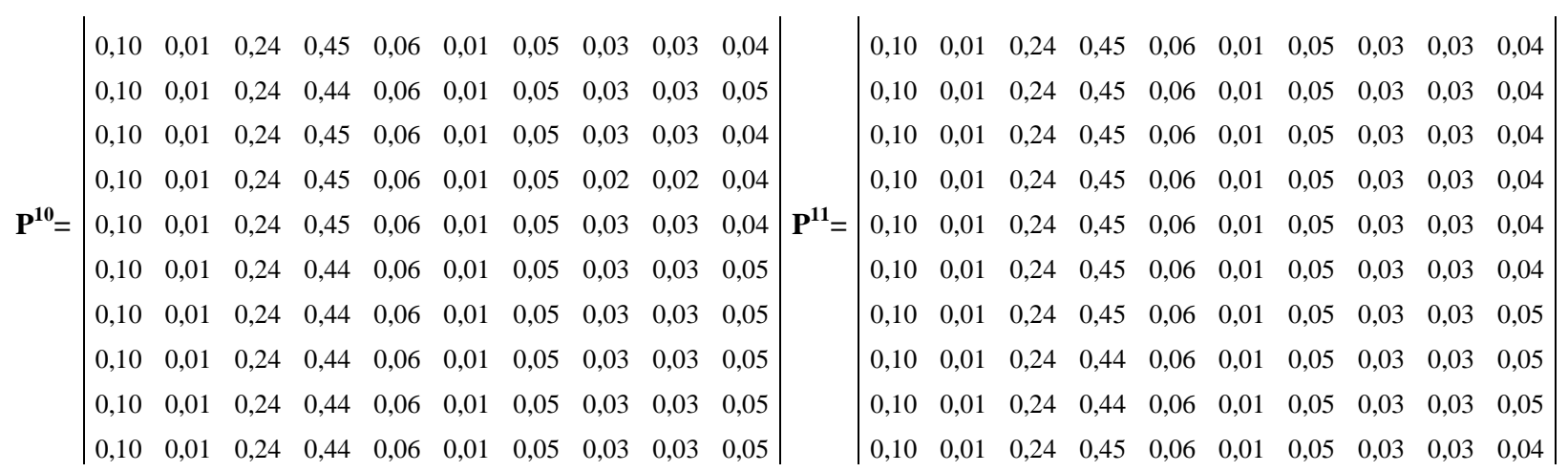

$\begin{array}{|llllllllll|}0,10 & 0,01 & 0,25 & 0,40 & 0,07 & 0,01 & 0,06 & 0,03 & 0,03 & 0,05\end{array}$ $\begin{array}{lllllllllll}0,10 & 0,01 & 0,24 & 0,42 & 0,07 & 0,01 & 0,05 & 0,03 & 0,03 & 0,05\end{array}$ $\begin{array}{llllllllll}0,09 & 0,01 & 0,23 & 0,49 & 0,05 & 0,00 & 0,04 & 0,02 & 0,02 & 0,04\end{array}$ $\mathbf{P}^{5}=\mid \begin{array}{lllllllllll}0,10 & 0,01 & 0,25 & 0,42 & 0,07 & 0,01 & 0,05 & 0,03 & 0,03 & 0,05\end{array}$ $\begin{array}{lllllllllll}0,10 & 0,01 & 0,24 & 0,41 & 0,07 & 0,01 & 0,05 & 0,03 & 0,03 & 0,06\end{array}$ $\begin{array}{lllllllllll}0,11 & 0,01 & 0,25 & 0,39 & 0,07 & 0,01 & 0,06 & 0,03 & 0,03 & 0,05\end{array}$ $\begin{array}{lllllllllll}0,11 & 0,01 & 0,24 & 0,39 & 0,07 & 0,01 & 0,06 & 0,03 & 0,04 & 0,05\end{array}$ $\begin{array}{lllllllllll}0,11 & 0,01 & 0,23 & 0,38 & 0,07 & 0,01 & 0,06 & 0,03 & 0,04 & 0,07\end{array}$ $\left|\begin{array}{llllllllll}0,10 & 0,01 & 0,25 & 0,40 & 0,08 & 0,01 & 0,05 & 0,03 & 0,03 & 0,06\end{array}\right|$

$\begin{array}{|llllllllll|}0,10 & 0,01 & 0,24 & 0,44 & 0,06 & 0,01 & 0,05 & 0,03 & 0,03 & 0,05\end{array}$ $\begin{array}{lllllllllll}0,10 & 0,01 & 0,24 & 0,43 & 0,06 & 0,01 & 0,05 & 0,03 & 0,03 & 0,05\end{array}$ $\begin{array}{lllllllllll}0,10 & 0,01 & 0,24 & 0,44 & 0,06 & 0,01 & 0,05 & 0,03 & 0,03 & 0,05\end{array}$ $\begin{array}{lllllllllll}0,09 & 0,01 & 0,24 & 0,46 & 0,06 & 0,01 & 0,05 & 0,02 & 0,02 & 0,04\end{array}$ $\begin{array}{lllllllllll}0,10 & 0,01 & 0,24 & 0,44 & 0,06 & 0,01 & 0,05 & 0,03 & 0,03 & 0,05\end{array}$ $\mathbf{P}^{7}=\mid \begin{array}{lllllllllll}0,10 & 0,01 & 0,24 & 0,43 & 0,06 & 0,01 & 0,05 & 0,03 & 0,03 & 0,05\end{array}$ $\begin{array}{lllllllllll}0,10 & 0,01 & 0,24 & 0,43 & 0,07 & 0,01 & 0,05 & 0,03 & 0,03 & 0,05\end{array}$ $\begin{array}{lllllllllll}0,10 & 0,01 & 0,24 & 0,42 & 0,07 & 0,01 & 0,05 & 0,03 & 0,03 & 0,05\end{array}$ $\begin{array}{lllllllllll}0,10 & 0,01 & 0,24 & 0,42 & 0,07 & 0,01 & 0,05 & 0,03 & 0,03 & 0,05\end{array}$ \begin{tabular}{|llllllllll}
0,10 & 0,01 & 0,24 & 0,43 & 0,06 & 0,01 & 0,05 & 0,03 & 0,03 & 0,05
\end{tabular} \mid

\begin{tabular}{|llllllllll}
0,10 & 0,01 & 0,24 & 0,45 & 0,06 & 0,01 & 0,05 & 0,03 & 0,03 & 0,04 \\
0,10 & 0,01 & 0,24 & 0,44 & 0,06 & 0,01 & 0,05 & 0,03 & 0,03 & 0,05
\end{tabular} \mid $\begin{array}{lllllllllll}0,10 & 0,01 & 0,24 & 0,44 & 0,06 & 0,01 & 0,05 & 0,03 & 0,03 & 0,05\end{array}$ $\begin{array}{llllllllll}0,10 & 0,01 & 0,24 & 0,44 & 0,06 & 0,01 & 0,05 & 0,03 & 0,03 & 0,05\end{array}$ $\begin{array}{lllllllllll}0,10 & 0,01 & 0,24 & 0,45 & 0,06 & 0,01 & 0,05 & 0,02 & 0,02 & 0,04\end{array}$ $\mathbf{P}^{9}=$ $\begin{array}{lllllllllll}0,10 & 0,01 & 0,24 & 0,44 & 0,06 & 0,01 & 0,05 & 0,03 & 0,03 & 0,05\end{array}$ $\begin{array}{llllllllll}0,10 & 0,01 & 0,24 & 0,44 & 0,06 & 0,01 & 0,05 & 0,03 & 0,03 & 0,05\end{array}$ $\begin{array}{lllllllllll}0,10 & 0,01 & 0,24 & 0,44 & 0,06 & 0,01 & 0,05 & 0,03 & 0,03 & 0,05\end{array}$ $\begin{array}{llllllllll}0,10 & 0,01 & 0,24 & 0,44 & 0,06 & 0,01 & 0,05 & 0,03 & 0,03 & 0,05\end{array}$ $\begin{array}{lllllllllll}0,10 & 0,01 & 0,24 & 0,44 & 0,06 & 0,01 & 0,05 & 0,03 & 0,03 & 0,05\end{array}$ $\begin{array}{llllllllll}0,10 & 0,01 & 0,24 & 0,44 & 0,06 & 0,01 & 0,05 & 0,03 & 0,03 & 0,05\end{array}$

$\begin{array}{llllllllll}0,10 & 0,01 & 0,24 & 0,45 & 0,06 & 0,01 & 0,05 & 0,03 & 0,03 & 0,04 \\ 0,10 & 0,01 & 0,24 & 0,45 & 0,06 & 0,01 & 0,05 & 0,03 & 0,03 & 0,04\end{array}$ $\begin{array}{llllllllll}0,10 & 0,01 & 0,24 & 0,45 & 0,06 & 0,01 & 0,05 & 0,03 & 0,03 & 0,04\end{array}$ 


$\mathbf{P}^{12}=\left|\begin{array}{llllllllll}0,10 & 0,01 & 0,24 & 0,45 & 0,06 & 0,01 & 0,05 & 0,03 & 0,03 & 0,04 \\ 0,10 & 0,01 & 0,24 & 0,45 & 0,06 & 0,01 & 0,05 & 0,03 & 0,03 & 0,04 \\ 0,10 & 0,01 & 0,24 & 0,45 & 0,06 & 0,01 & 0,05 & 0,03 & 0,03 & 0,04 \\ 0,10 & 0,01 & 0,24 & 0,45 & 0,06 & 0,01 & 0,05 & 0,03 & 0,03 & 0,04 \\ 0,10 & 0,01 & 0,24 & 0,45 & 0,06 & 0,01 & 0,05 & 0,03 & 0,03 & 0,04 \\ 0,10 & 0,01 & 0,24 & 0,45 & 0,06 & 0,01 & 0,05 & 0,03 & 0,03 & 0,04 \\ 0,10 & 0,01 & 0,24 & 0,45 & 0,06 & 0,01 & 0,05 & 0,03 & 0,03 & 0,04 \\ 0,10 & 0,01 & 0,24 & 0,45 & 0,06 & 0,01 & 0,05 & 0,03 & 0,03 & 0,04 \\ 0,10 & 0,01 & 0,24 & 0,45 & 0,06 & 0,01 & 0,05 & 0,03 & 0,03 & 0,04 \\ 0,10 & 0,01 & 0,24 & 0,45 & 0,06 & 0,01 & 0,05 & 0,03 & 0,03 & 0,04\end{array}\right|$

Tablo 8'den yola çıkılarak uzun dönem denge durumu 12. Adımda bulunmuştur. Denge durum vektörü;

$$
V=\left[\begin{array}{llllllllll}
0,10 & 0,01 & 0,24 & 0,45 & 0,06 & 0,01 & 0,05 & 0,03 & 0,03 & 0,04
\end{array}\right]^{\prime} \text { dür. }
$$

Yani denge durum vektörü ile dikkate aldığımız örneklemde akıllı telefon markalarının uzun dönemde tercih edilme olasılıklarının Tablo 9'daki gibi olması beklenir.

Tablo 9: Denge Durum Olasılıkları/ Uzun Dönemde Tercih Edilme Olasılıkları

\begin{tabular}{|c|l|}
\hline Markalar & \multicolumn{1}{|c|}{ Uzun Dönem Tercih edilme Olasılıkları } \\
\hline LG & 0,10 \\
\hline Nokia & 0,01 \\
\hline Samsung & 0,24 \\
\hline İpone & 0,45 \\
\hline GM & 0,06 \\
\hline Turkell & 0,01 \\
\hline Sony & 0,05 \\
\hline HTC & 0,03 \\
\hline Asus & 0,03 \\
\hline Casper & 0,04 \\
\hline
\end{tabular}

Tablo 5'e göre akıllı telefon tercihlerinde herhangi bir dışsal etki olmadığı durumda gelecekte kullanıcıların \%45 ile İphone,\%24 ile Samsung, \% 6 ile General Mobile, \% 5 ile Sony , \% 4 ile Casper ve \%3 ile HTC ve yine\% 3 ile ASUS marka akıllı telefon kullanıyor olacakları sonucuna ulaşılmışırı. Başlangıçta \% 32 ile Samsung liderliğini korurken, uzun dönemde liderliği \% 45 ile İphone alacaktır. Bu durum şuan ki kullanım oranı \%27 olan İphone'nun uzun dönemde payını neredeyse iki katına çıkaracağı sonucuna ulaştırmaktadır.

\section{SONUC}

Bu çalışmada akıllı telefon kullanıcılarının marka tercihlerinin uzun dönemde nasıl olacağı araştırılmışır. Araştırmaya katılanlara şuanda kullanmakta oldukları telefonların markaları ve bir önceki kullandıkları telefon markaları sorulmuştur. Burada kullanıcıların gelecekteki marka tercihini, kullanmış olduğu markanın etkilediği düşünülmüştür. Çalışmada akıllı telefon marka tercihleri etkileyen faktörler bağlamında yoğun rekabette olan markalardan lider konumlarını sürdüren Samsung ve íphone marka telefonlara dikkat çekilmiştir. Araştırmada analiz yöntemi olarak uzun dönem akıllı telefon markalarının tercih edilme ya da kullanılma olasılığını hesaplamak için uzun dönem projeksiyon sağlayan Markov Zincirlerinden yararlanılmıştır. Her bir akıllı telefon markasından diğer markalara tercih oranları (geçiş oranları) ve her bir marka için marka bağımlııkları hesaplanmıştır. Ayrıca firmalar için uzun dönemdeki pazar payları için bir öngörü oluşturulmuştur.

Uygulama sonrasında kullanıcıların şuanda kullanmakta oldukları akıllı telefon marka tercih oranları sırasıyla \%32 ile Samsung, \%27 ile İphone, \%12,4 ile LG ve \%8,4 ile GM, \%5,9 ile Sony, \% 5.2 ile HTC diğer markalara oranla en çok tercih edilen markalar olmuşlardır. Aynı kullanıcıların bir önceki kullandıkları akıllı telefon markalarındaki tercih oranları sırasıyla \%47 ile Samsung \% 18 ile Nokia, \% 15,6 ile İphone ,\% 6, 5 ile Sony ve \%3,9 ile LG şeklinde hesaplanmıştır. Geçmişten günümüze Samsung ve Nokia pay kaybederken, İphone, LG, Sony marka cep telefonları pay kazanmıştır. 
Uygulama sonrasında kullanıcıların akıllı telefon marka tercihlerine dışsal bir etkinin olmaması durumunda (12. Adım= denge durumu sonrasında) gelecekte kullanıcıların \% 45 'nin İphone, \% 24'nün Samsung, \% 10'nun LG, \% 6'sının GM,\% 5 'nin Sony marka akıllı telefon kullanacağı sonucuna ulaşıımıştır. Bu çalışma ön araştırma niteliği şeklinde Celal Bayar Üniversitesi Uygulamalı Bilimler Yüksekokulu birinci sınıf öğrencileri arasından 153 katılımcı ile yapılmıştır. Araştırma örneklem büyüklügünün artırılması daha çok marka sayısına ulaşılması ve markaların gelecek dönemde gerçekleşecek piyasa pazar paylarının belirlenmesi için önemlidir. Bu nedenle analizin daha büyük ana kütleler üzerinde uygulanması, akıllı telefon üreten firmalar içinde gelecekte markasının alacağı pazar payı ve diğer markalardaki pazar payı değişiminin bilinmesi, kendi pazarlama stratejilerini belirleme ve geliştirmeleri için önerilmektedir.

\section{KAYNAKLAR}

Aaker, J. L. (1999), The Malleable Self: The Role of Self-Expression in Persuasion. Journal of Marketing Research, 36 (1), $45-57$.

Alp, S.\& Öz, E. (2009). Markov Zinciri Yöntemi İle Taşınabilir Bilgisayar Tercihlerinin Analizi. Akademik İncelemeler. 4(2). 37-55.

Arıtan, T. \& Akyüz, A.M. (2015).Tüketicilerin Otomobil Markalarına Yönelik Marka Sadakatleri Ve Tercihleri Üzerine Bir Araştırma. Uluslararası Yönetim İktisat ve İşletme Dergisi, 11 (26). 195-220.

Aydoğdu Karaaslan, i. \& Budak, L. (2012). Üniversite Öğrencilerinin Cep Telefonu Özelliklerini Kullanımlarının ve Gündelik İletişimlerine Etkisinin Araştırılması. Journal of Yasar University. 26(7) 4548 - 4525.

Bişkin, F. Markanın Pazarlama Açısından Önemi Ve Tüketici Tercihleri-Memnuniyeti Çerçevesinde Otomobil Sahipleri Üzerinde Bir Araştırması IïBF Sosyal ve Ekonomik Araştırmalar Dergisi.

Büyüktatlı, F. ,İşbilir, S. \& İpekçi Çetin, E. (2013). Markov Analizi ile Yıllık Ödeneklere Bağlı Bir Tahmin Uygulaması. Uluslararası Alanya İşletme Fakültesi Dergisi 5(1), 1-8.

Can, T. (2006). Sektörler arası ilişkilerin Markov zincirleri ile analizi ve tahmini: türkiye örneği. Derin Yayınları. Aralık 2006. İstanbul.

Ching, W.K., Fung, E.S., Ng, M.K. (2002). A Multivariate Markov Chain Model for Categorical Data Sequences and Its Applications in Demand Predictions. IMA Journal of Management Mathematics,13,187-199.

Çetin, N.G.\& Alp, S.(2016). Cep Telefonu Marka Tercihlerinin Markov Zincirleri ile Analizi. Erzincan Üniversitesi Fen Bilimleri Enstitüsü Dergisi 9(3), 126-138.

Çiftçi, S \& Cop, R. (2007). Marka ve Marka Yönetimi Kavramları: Üniversite Öğrencilerinin Kot Pantolon Marka Tercihlerine Yönelik Bir Araştırma. Finans Politik \& Ekonomik Yorumlar. 44 (512).69-88.

Durmaz, Y. \& Şerbetçi, G. (2016). Üniversite Öğrencilerinin Cep Telefonu Tercihlerini Etkileyen Faktörler ve Bir Uygulama. Akademik Araştırmalar ve Çalışmalar Dergisi. 8 (14). 109-136.

Ergeç, F. (1996). Markov Analizi İle Hisse Senedi Fiyatlarının Tahminlenmesi. İstanbul Üniversitesi İşletme Fakültesi Dergisi 25(2),123-151.

Gölbaşı Şimşek, G. \& Noyan, F. (2009). Türkiye'de Cep Telefonu Cihazı Pazarında Marka Sadakati İçin Bir Model Denemesi. ODTÜ Gelişme Dergisi, 36 (Haziran), 2009, 121-159.

Gülmez, M. (2005). “Üniversite Öğrencilerinin Cep Telefonu Satın Alma ve Kullanımını Etkileyen Faktörler: Sivas Cumhuriyet Üniversitesi Tokat Gaziosmanpaşa Üniversitelerinde Bir Uygulama”, Erciyes Üniversitesi İktisadi ve İdari Bilimler Fakültesi Dergisi, Sayı: 24.

Gülmez, M. \& Dörtyol, İ.T.(2009), Açıklamalı Pazarlama Sözlüğü, Detay Yayıncılık. Ankara.

Gürbüz, H.\& Köse, T. (2002). Şüpheli Alacak Zararlarının Büyüklüklerinin Markov Zinciri Teorisi İle Hesaplanması. Afyon Kocatepe Üniversitesi, İ.i. B.F. Dergisi 4(2). 49-66.

İlarslan, K. (2014). Hisse Senedi Fiyat Hareketlerinin Tahmin Edilmesinde Markov Zincirlerinin Kullanılması: IMKB 10 Bankacılık Endeksi İşletmeleri Üzerine Ampirik Bir Çalışma. Journal of Yaşar University. 9 (35). 6185-6198.

Jacop, J \& Chestnut, R.W.(1978). Brand Loyalty, Measurement and Management. New York: John Wiley \& Sons.

McClatchey, S. (2006). The Consumption Of Mobile Services By Australian University Students, International Journal Of Mobile Marketing. $1(1)$.

Khan, S. \& Rohi, S. (2013). Investigating The Factors Affecting Youth Brand Choice For Mobile Phones Purchase - A Study of Private Universities Students of Peshawar. Management \& Marketing Challenges Forthe Knowledge Society, S. 8 (2), s. 369-384.

Koçak, K.\& Şen, Z. (1998). Kurak ve Yağışlı Gün Oluşumlarının Markov Zinciri Yaklaşımı ile Uygulamalı Incelenmesi. Tr. J. of Engineering and Environmental Science. 22 (1998) , $479-487$

Kuşku Özdemir,E. \& Güzeloğlu, E. B. (2015). Akıllı Telefonlar ve Marka Değer Algıları: Üniversite Öğrencileri Üzerine Bir Araştırma. Uluslararası Sosyal Araştırmalar Dergisi. 8(40).730-742.

Önalan, Ö. (2010). Stokastik Süreçler. AVCıOL Basım Yayın ( Birinci Baskı). İstanbul

Ömürbek, N. \& Şimşek, A. (2012). Üniversite Öğrencilerinin Cep Telefonu Tercihlerinin Analitik Hiyerarşi Prosesi ile Belirlenmesi. Niğde Üniversitesi iißBF Dergisi, 2012, 5(1).116-132. 
Özdağolu, A, Özdağoğlu, G. \& Kurt Gümüş, G. (2012). Altın Fiyatındaki Dağılımların Markov Zinciri Ile Analizi: Uzun Erimli Olasılıklar. Erciyes Üniversitesi İktisadi ve İdari Bilimler Fakültesi Dergisi, 40 (Haziran-Aralık 2012). 119-142.

Özdemir, A. Y. ve Gümüşoğlu, Ş. 2007. “işletmelerin Tahminleme Sorunlarının Çözümlenmesinde Markov Zincirleri Analizinin Uygulanması.” Dokuz Eylül Üniversitesi Sosyal Bilimler Enstitüsü Dergisi, 9 (1): 337-359.

Özdemir, A.\& Demireli, E. (2014). Hisse Senedi Fiyat Verimliliğinin Markov Zincirleri İle Analizi BIST Teknoloji Endeksi Hisse Senedi Fiyatları Üzerine Bir Uygulama. Verimlilik Dergisi, 41-60.

Öztemiz, H. H. (2016). Lojistik Firmalarında Performans Ölçümü: Tek Skorlu Dengelenmiş Skor Kart (Balanced Score Card) Ve Markov Zinciri Uygulaması (Yayınlanmamış Yüksek Lisans Tezi). Celal Bayar Üniversitesi Sosyal Bilimler Enstitüsü. Manisa.

Pride, W. M. ve Ferrell, O.C. (2000). Marketing Concepts and Strategies. Houghton Mifflin Company, New York.

Soykan, Y. (2015). Markov Zincirleri İle Pazar Payı Araştırma Modeli Ve Otomobil Lastiği Pazarında Bir Uygulama. Dumlupınar Üniversitesi Sosyal Bilimler Dergisi, 27(27).95-108.

Şentürk, S. \& Alp, S. (2016). Mobil Operatör ve Internet Servis Sağlayıcı Tercihlerinin Markov Zinciri Yöntemi ile Analizi. Gaziosmanpaşa Bilimsel Araştırma Dergisi 13(2016) 133-151.

Uğur, N.G. \& Turan, A. H. (2015). Üniversite Öğrencilerinin Mobil Uygulamaları Kabulü ve Kullanımı: Sakarya Üniversitesi Örneği. İnternet Uygulamaları ve Yönetimi Dergisi. 6(2). 63-79.

Uluslararası Telekominasyon Birliği- Mobile-Cellular Subscriotions . 2000-2015 arası dönem. http://www.itu.int/en/ITUD/Statistics/Pages/stat/default.aspx. Erişim Tarihi:11.04.2017.

Tatı, H. (2015). Akıllı Telefon Seçiminin Belirleyicileri: Üniversite Öğrencileri Üzerine Bir Uygulama. Çankırı Karatekin Üniversitesi İktisadi ve idari bilimler fakülte dergisi. 2 (-). 549-567.

Yavuz, S. \& Karabulut, T. (2016). Markov Analizi İle Üniversite Öğrencilerinin Cep Telefonu Marka Tercihlerinin Belirlenmesi. Dicle Üniversitesi Sosyal Bilimler Enstitüsü Dergisi. 8(17).221-235.

Yaşa, E. \& Bozyiğit, S. (2012). Y Kuşağı Tüketicilerinin Cep Telefonu ve GSM Operatörleri Tercihi: Mersin ilindeki Üniversite Öğrencilerinin Tercihlerini Belirlemeye Yönelik Pilot Bir Araştırma. Cag University Journal of Social Sciences, 9(1). $29-42$. 